

http://journal.uinsgd.ac.id/index.php/biodjati

\title{
SURVEY DAN PENDOKUMENTASIAN SAYURAN LOKAL DI PASAR TRADISIONAL KABUPATEN DAN KOTA KEDIRI, JAWA TIMUR
}

\author{
Kartika Yurlisa1, Moch. Dawam Maghfoer ${ }^{2}$, Nurul Aini ${ }^{3}$, Wiwin Sumiya D. Y.4, \\ Paramyta Nila Permanasari ${ }^{5}$
}

\author{
1,2,3,4,5 Jurusan Budidaya Pertanian, Fakultas Pertanian, Universitas Brawijaya
}

\begin{tabular}{l}
\hline Diterima 21 April 2017 \\
Disetujui 29 Mei 2017 \\
Publish 31 Mei 2017 \\
\hline Korespondensi : \\
Jalan Veteran, Malang 65145 \\
email: \\
${ }^{1}$ kartikayurlisa2@gmail.com \\
\hline
\end{tabular}

e-ISSN : 2541-4208

p-ISSN : 2548-1606
Abstrak. Upaya pendokumentasian sayuran lokal sangatlah penting untuk dilakukan. Hal ini disebabkan keragaman sayuran lokal yang terancam punah oleh perubahan zaman, alih fungsi lahan, dan pola konsumsi masyarakat. Paper ini mendiskusikan keragaman sayuran lokal di Kabupaten dan Kota Kediri, Jawa Timur. Metode penelitian menggunakan survey eksplorasi melalui teknik wawancara terstruktur. Daerah survey mencangkup 15 pasar tradisional yaitu Gurah, Pare, Induk Pare, Pagu, Plemahan, Ngadiluwih, Grogol, Wates, Gempengrejo, Papar, Mojo, Pahing, Setono Betek, Grosir Ngronggo dan Bandar. Responden yang diwawancarai pada saat survey adalah pedagang sayur yang menjual sayuran lokal. Total jumlah responden di 15 pasar tradisional adalah 40 orang. Data yang didapatkan dianalisis secara deskriptif menggunakan software excel. Paper ini mendokumentasikan 28 spesies dari 16 famili tanaman. Sayuran lokal yang banyak diperjualbelikan adalah kenikir, kacang panjang, kangkung dan kemangi. Sedangkan sayuran yang dijumpai sedikit diperjualbelikan adalah kucai, selada air, nangka, dan terung pokak. Sayuran lokal khas daerah tersebut adalah sintrong dan sembukan. 61\% sayuran lokal yang ditemui sudah dibudidayakan, $21 \%$ dibudidayakan tetapi masih dipungut dari alam, sisanya sebanyak $18 \%$ merupakan sayuran yang masih dipungut dari alam. Sayuran yang dipungut dari alam seperti pakis, sintrong, sembukan, bambu dan lamtoro mempunyai potensi untuk didomestikasi menjadi tanaman budidaya.

Kata kunci: Sayuran lokal, Kediri, Jawa Timur
Abstract. The efforts to documentation local vegetables is very important because its diversity is threatened with extinction due to the changing of times, land conversion, and consumption pattern. This paper discussed about the diversity of local vegetables in District and City of Kediri, East Java. The methods of the research using exploratory surveys through structured interview techniques. The area survey covers of 15 traditional markets namely Gurah, Pare, Induk Pare, Pagu, Plemahan, Ngadiluwih, Grogol, Wates, Gempengrejo, Papar, Mojo, Pahing, Setono Betek, Induk Ngronggo and Bandar. The respondents interviewed during the survey were vegetable sellers selling local vegetables. The total number of respondents in 15 traditional markets is 40 people. The data obtained is analyzed descriptively using excell software. The paper documents 28 species of 16 plant families. Common traded local vegetables are kenikir, 


\section{Jurnal Biodjati, 2 (1) 2017

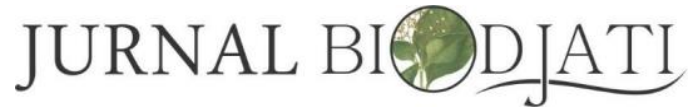

http://journal.uinsgd.ac.id/index.php/biodjati

kacang panjang, kangkung and kemangi. While the vegetables that are found less traded are kucai, selada air, nangka and terung pokak. The typical local vegetables of the area are sintrong and sembukan. The local vegetables approximately about $61 \%$ encountered have been cultivated, $21 \%$ cultivated but still collected from nature, the remaining $18 \%$ are vegetables that are still collected from nature. Vegetables picked from nature such as pakis, sintrong, sembukan, bambu and lamtoro have the potential to be domesticated into cultivated plants.

Key words: Local vegetables, Kediri, East Java

\section{Cara Sitasi}

Yurlisa, K., Maghfoer, M. D., Aini, N., Sumiya, W. D. Y. \& Permanasari, P. N. (2017). Survey dan Pendokumentasian Sayuran Lokal di Pasar Tradisional Kabupaten dan Kota Kediri, Jawa Timur. Jurnal Biodjati, 2 (1), 52-63.

\section{PENDAHULUAN}

Sayuran merupakan salah satu kebutuhan pangan manusia. Saat ini pertumbuhan jumlah penduduk sangat pesat sehingga diduga pada masa mendatang akan terdapat kesenjangan antara jumlah penduduk dengan kebutuhan pangan. Menurut teori Malthus, jumlah penduduk meningkat secara geometris (deret ukur), sedangkan produksi pangan meningkat secara arismatik (deret hitung) (Rosyetti, 2009). Terkait dengan kebutuhan pangan yang terus meningkat, maka diperlukan upaya peningkatan pemanfaatan terhadap keanekaragaman tanaman untuk memenuhi kebutuhan manusia (Pugalenthi et al., 2005). Diantara keanekaragaman pangan yang terdapat di Indonesia, maka sayuran lokal merupakan sumber pangan yang berpotensi dapat memenuhi kebutuhan gizi manusia.

Keanekaragaman sayuran merupakan kekayaan biodiversitas yang sangat penting dalam kehidupan. Kanekaragaman sayuran merepresentasikan sumber makanan, pakan, obat-obatan dan banyak produk lainnya dalam kehidupan di bumi. Indonesia memiliki nutrisi kekayaan sayuran dengan kandungan nutrisi tinggi, bermanfaat bagi kesehatan dan berpotensi secara ekonomi. Sayuran dapat didefinisikan sebagai tanaman sukulen atau bagian dari tanaman yang dikonsumsi sebagai pelengkap makanan, dengan bahan karbohidrat, biji-bijian atau umbi (Grubben et al., 1994). FAOSTAT (2007) mendefinisikan bahwa sayuran mengandung $70-95 \%$ air, yang pada umumnya ringan ketika dikeringkan.

Sayuran lokal merupakan sayuran asli daerah yang telah banyak diusahakan dan dikonsumsi sejak zaman dahulu atau sayuran introduksi yang telah berkembang lama dan dikenal masyarakat di suatu daerah tertentu (Suryadi dan Kusamana, 2004). Sayuran lokal mempunyai harga yang relatif murah, dan secara tradisional sayuran lokal merupakan salah satu komponen pola tanam, serta pemanfaatannya oleh petani memiliki keunggulan yang komparatif (Marsh, 1998).

Sayuran lokal merupakan bagian dari keanekaragaman hayati yang dimiliki Indonesia yang dikenal sebagai Mega Biodiversity Country. Mempertimbangkan arti penting sayuran sebagai bahan pelengkap makanan utama, maka sayuran ini dapat dieksploitasi pada tingkat komersial. Kandungan nutrisi yang beragam seperti vitamin A, B, C, kalium, besi, protein dan senyawa antioksidan mengindikasikan bahwa budidaya dan konsumsi dari sayuran dapat 


\section{Jurnal Biodjati, 2 (1) 2017

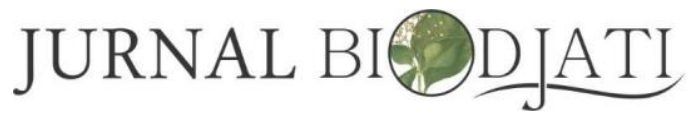

http://journal.uinsgd.ac.id/index.php/biodjati

membantu dalam menghadapi malnutrisi di Indonesia (Becker, 2003 ; Madalla et al., 2013). Meningkatnya kebutuhan akan pangan yang bergizi tinggi, maka kegiatan koleksi dan pemanfaatan dari sayuran lokal menjadi penting untuk dilakukan agar sayuran tersebut tidak punah oleh perubahan zaman, alih fungsi lahan maupun pola konsumsi masyarakat. Informasi tersebut sangat penting untuk meletakkan dasar informasi sebagai pedoman pola konsumsi untuk komunitas daerah tersebut, menerapkan teknologi budidaya untuk mendukung keamanan pangan dan untuk menentukan potensi kandungan fitokimia dan farmasi.

Indonesia memiliki kurang lebih 40.000 jenis tumbuhan yang diantaranya terdiri dari 250 jenis sayuran, 12.000 jenis jamur, 1.500 jenis tumbuhan paku, 150 jenis bambu dan rotan serta lainnya (Abrori, 2016). Keanekaragaman ini tersebar pada seluruh provinsi termasuk di Jawa Timur. Kabupaten dan Kota Kediri merupakan kawasan dengan pengembangan pertanian yang cukup pesat di Jawa Timur. Beberapa kecamatan di Kediri telah ditetapkan sebagai kawasan agropolitan. Berdasarkan Rencana Tata Ruang Wilayah Kabupaten Kediri Tahun 2010 dan Masterplan Agropolitan Kabupaten Kediri Tahun 2006, maka salah satu wilayah yang ditetapkan sebagai kawasan Agropolitan Pakancupung dengan komoditas unggulan berupa sayuran adalah kecamatan Pare, Kandangan, Puncu dan Kepung (Sari dan Santoso, 2016).

Daerah Kediri yang sebagian besar merupakan dataran rendah $\left(\begin{array}{llll} \pm 67 & \mathrm{~m} & \mathrm{dpl}\end{array}\right)$ menyediakan berbagai tanaman yang sebagian telah dimanfaatkan secara turun-temurun sejak nenek moyang sebagai sayuran. Sayuran tersebut dapat dikategorikan sebagai sayuran lokal. Seiring perubahan zaman, alih fungsi lahan, dan pola konsumsi masyarakat maka keberadaan sayuran lokal mulai langka. Sayuran tersebut pada umumnya masih dipungut langsung dari alam untuk dikonsumsi sendiri atau diperjualbelikan di pasar tradisional. Hal ini mengindikasikan bahwa upaya konservasi genetik sayuran lokal perlu dilakukan yaitu melalui usaha budidaya pertanian.

Penelitian bertujuan untuk mendapatkan informasi mengenai sayuran lokal yang diperjualbelikan oleh para pedagang sayur di pasar tradisional Kabupaten dan Kota Kediri, Provinsi Jawa Timur. Penelitian merupakan bagian dari penelitian pendahuluan mengenai potensi sayuran lokal Provinsi Jawa Timur.

\section{BAHAN DAN METODE}

Metode penelitian yang digunakan adalah survey eksplorasi melalui teknik wawancara terstruktur menggunakan kuesioner yang disajikan secara lisan. Kegiatan survey dilakukan pada bulan Februari-Maret 2017.

\section{Daerah Penelitian}

Kabupaten dan Kota Kediri, Provinsi Jawa Timur dipilih sebagai area penelitian, daerah ini terletak pada $07^{0} 36^{\prime} 12^{\prime \prime}$ - $8^{0} 0$ ' 32 '" LS, 111 $47^{\prime} 05^{\prime \prime}-112^{0} 18^{\prime} 20^{\prime \prime}$ BT dan ketinggian $\pm 67 \mathrm{~m}$ dpl (Pemkab. Kediri, 2016) (Gambar 1). Area penelitian terdiri dari perbukitan dan pegunungan dengan lembah kecil dan dataran, luas dari area adalah 1449,4 $\mathrm{km}^{2}$. Suhu udara berkisar antara $23-31^{\circ} \mathrm{C}$.

Lokasi survey mencangkup 15 pasar tradisional Kabupaten dan Kota Kediri (Tabel 1). Pemilihan lokasi berdasarkan sebaran lokasi pasar dan keberagaman tingkatan pasar. Sasaran responden adalah para pedagang sayuran lokal. Data yang dikumpulkan meliputi nama lokal, bagian sayuran yang 


\section{JURNAL BIDDATI}

\section{http://journal.uinsgd.ac.id/index.php/biodjati}

dijual, asal sayuran (dibudidayakan atau dipungut dari alam). Analisis data dilakukan secara deskriptif. Sayuran yang diperoleh didokumentasikan dengan kamera dan juga dilakukan pengambilan sampel sayuran untuk keperluan identifikasi tanaman.

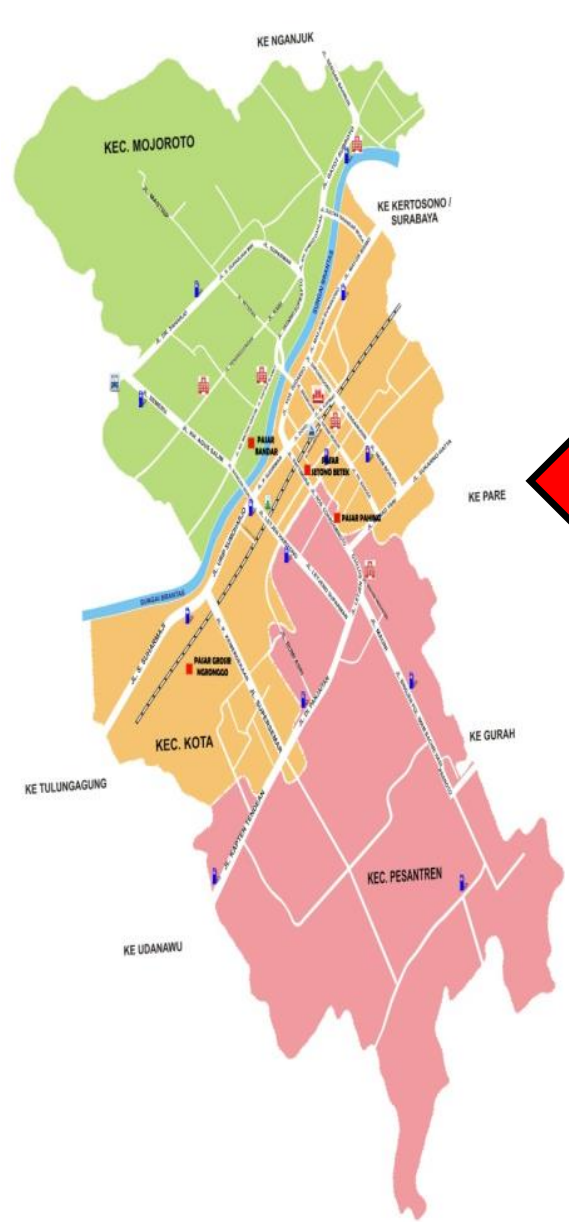

(a)

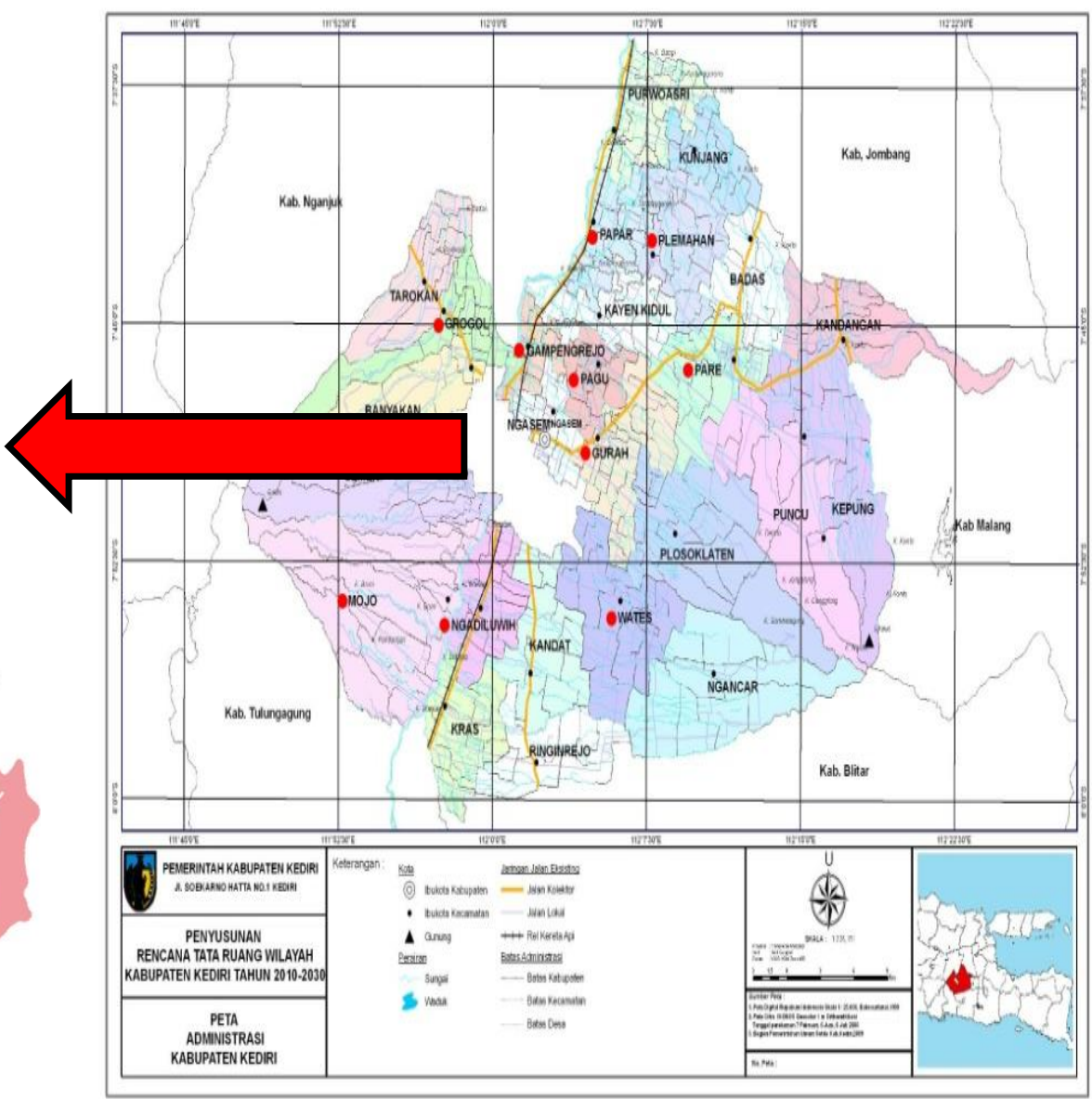

(b)

Gambar 1. Peta lokasi dari area penelitian yang menunjukkan area survey : (a) Kota Kediri dan (b) Kabupaten Kediri

Tabel 1. Lokasi dan nama pasar tradisional yang dijadikan tempat penelitian

\begin{tabular}{cccc}
\hline No. & Lokasi & Nama Pasar & $\begin{array}{c}\text { Jumlah } \\
\text { Responden }\end{array}$ \\
\hline 1 & Kab. Kediri & Gurah & 2 \\
2 & Kab. Kediri & Pare & 3 \\
3 & Kab. Kediri & Induk Pare & 3 \\
4 & Kab. Kediri & Pagu & 2 \\
5 & Kab. Kediri & Plemahan & 2 \\
6 & Kab. Kediri & Ngadiluwih & 4 \\
7 & Kab. Kediri & Grogol & 4
\end{tabular}

\begin{tabular}{cccc}
\hline No. & Lokasi & Nama Pasar & $\begin{array}{c}\text { Jumlah } \\
\text { Responden }\end{array}$ \\
\hline 8 & Kab. Kediri & Wates & 3 \\
9 & Kab. Kediri & Gampengrejo & 3 \\
10 & Kab. Kediri & Papar & 2 \\
11 & Kab. Kediri & Mojo & 2 \\
12 & Kota Kediri & Pahing & 2 \\
13 & Kota Kediri & Setono Betek & 4 \\
14 & Kota Kediri & Grosir Ngronggo & 2 \\
15 & Kota Kediri & Bandar & 2 \\
\hline
\end{tabular}




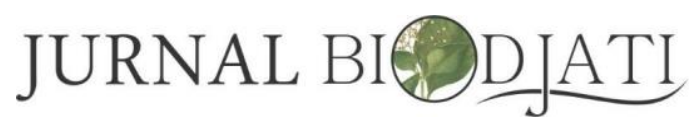

http://journal.uinsgd.ac.id/index.php/biodjati

\section{Pengumpulan Data}

Sebelum melakukan penelitian, observasi pre-eliminari dan acak dilakukan. Kuisioner terbuka dengan pedagang sebagai responden disusun untuk mendapatkan data kualitatif sayuran lokal. Kualifikasi responden adalah para pedagang sayuran yang menjual sayuran lokal atau mayoritas menjual sayuran lokal pada saat kegiatan survey dilakukan. Total responden berjumlah 40 orang yang tersebar pada 15 pasar (Tabel 1). Informasi terkait grup umur, jenis kelamin, status pernikahan, dan tingkat pendidikan disajikan pada Tabel 2.

Tabel 2. Data responden yang diwawancarai di lokasi penelitian

\begin{tabular}{|c|c|c|}
\hline No. & Responden & Frekuensi \\
\hline \multirow[t]{3}{*}{1} & Status kependudukan: & \\
\hline & Asli daerah tersebut & $87,50 \%$ \\
\hline & Pendatang & $12,50 \%$ \\
\hline \multirow[t]{3}{*}{2} & Jenis Kelamin & \\
\hline & Laki-laki & $15 \%$ \\
\hline & Perempuan & $85 \%$ \\
\hline \multirow[t]{3}{*}{3} & Status Pernikahan: & \\
\hline & Belum menikah & $0 \%$ \\
\hline & Menikah & $100 \%$ \\
\hline \multirow[t]{6}{*}{4} & Tingkat Pendidikan & \\
\hline & SD & $45,00 \%$ \\
\hline & SMP & $20 \%$ \\
\hline & SMA & $22,50 \%$ \\
\hline & Perguruan tinggi & $2,50 \%$ \\
\hline & Tidak sekolah & $10 \%$ \\
\hline \multirow[t]{5}{*}{5} & Usia & \\
\hline & $10-25$ tahun & $0 \%$ \\
\hline & 26-40 tahun & $20 \%$ \\
\hline & 41-60 tahun & $57,50 \%$ \\
\hline & $61 \sim$ tahun ke atas & $22,50 \%$ \\
\hline 6 & $\begin{array}{l}\text { Jumlah responden yang } \\
\text { diwawancarai }\end{array}$ & 40 \\
\hline
\end{tabular}

\section{Identifikasi Spesies Tanaman}

Sampel sayuran lokal yang diperjualbelikan di pasar dikumpulkan dari area penelitian, kemudian dibawa ke laboratorium dan diindentifikasi menggunakan pustaka (buku determinasi) menggunakan buku determinasi : pedoman pustaka Flora of Java Volume I, II, III (Backer dan Bakhuzein Van den Brink ,1968), A Practical Field Guide to Weeds of Rice in Asia (Caton et al., 2010), dan Weed Identification (Naidu, 2012). Kemudian dilakukan pendataan bentuk tumbuh tanaman.

\section{Analisis Data}

Analisis data frekuensi sitasi dilaporkan sebagai persentase dan proporsi. Tiap tanaman yang didapatkan dari responden yang termasuk sebagai sayuran lokal dihitung sebagai frekuensi sitasi.

\section{HASIL}

\section{Arti Penting Tanaman dan Keanekaragaman Tanaman}

Hasil observasi langsung di pasar tradisonal memperlihatkan bahwa keragaman sayuran lokal Kediri yang diperjualbelikan tergolong tinggi (>20 spesies tanaman). Hasil survey dan wawancara disusun dalam tabel berdasarkan susunan alfabet nama famili tanaman. Inventarisasi detailnya meliputi nama ilmiah, nama lokal, famili tanaman, bentuk tumbuh tanaman dan bagian tanaman yang dijual. Daftar sayuran lokal yang diperjualbelikan dan dikonsumsi di Kabupaten dan Kota Kediri disajikan pada Tabel 3. 
http://journal.uinsgd.ac.id/index.php/biodjati

Tabel 3. Daftar sayuran lokal yang diperjualbelikan dan dikonsumsi di Kabupaten dan Kota Kediri

\begin{tabular}{|c|c|c|c|c|}
\hline Nama Ilmiah & Nama Lokal & $\begin{array}{l}\text { Bentuk } \\
\text { tumbuh tan. }\end{array}$ & $\begin{array}{c}\text { Bagian sayuran } \\
\text { yang dijual }\end{array}$ & $\begin{array}{c}\text { Frekuensi } \\
\text { Sitasi }\end{array}$ \\
\hline \multicolumn{5}{|l|}{ Famili Alliaceae } \\
\hline Allium schoenoprasum L. & Kucai & Semak & Daun, Bunga & 1 \\
\hline \multicolumn{5}{|l|}{ Famili Araceae } \\
\hline Xanthosoma sagittifolium & Lompong & Semak & Batang & 2 \\
\hline Musa paradisiaca $\mathrm{L}$. & Ontong & Pohon & Bunga & 4 \\
\hline \multicolumn{5}{|l|}{ Famili Asteraceae } \\
\hline Pluchea indica & Beluntas & Semak & Daun & 2 \\
\hline Cosmos caudatus Kunth. & Kenikir & Semak & Batang, Daun & 24 \\
\hline Crassophecephalum crepidiodes & Sintrong & Herba & Batang, Daun & 3 \\
\hline \multicolumn{5}{|l|}{ Famili Brassicaceae } \\
\hline Nasturtium officinale & Selada Air & Herba & Daun & 1 \\
\hline \multicolumn{5}{|l|}{ Famili Caricaceae } \\
\hline Carica papaya $\mathrm{L}$. & Pepaya & Pohon & Daun, Buah & 15 \\
\hline \multicolumn{5}{|l|}{ Famili Convolvulaceae } \\
\hline Ipomea aquatic & Kangkung & Herba & Batang, Daun & 23 \\
\hline Ipomea batatas $\mathrm{L}$. & Ubi Jalar & Semak & Daun & 6 \\
\hline \multicolumn{5}{|l|}{ Famili Cucurbitaceae } \\
\hline Lagenaria siceraria & Blonceng & Memanjat & Buah & 3 \\
\hline Sechium edule (Jacq.) Swartz & Labu Siam & Memanjat & Buah & 3 \\
\hline Luffa acutangula L. Roxb. & Oyong & Memanjat & Buah & 11 \\
\hline Momordica charantina & Paria & Memanjat & Buah & 2 \\
\hline \multicolumn{5}{|l|}{ Famili Drypoteridaceae } \\
\hline Arcypteris irregularis (C. Presl) Ching & Pakis & Herba & Batang, Daun & 3 \\
\hline \multicolumn{5}{|l|}{ Famili Euphorbiaceae } \\
\hline Manihot esculanta $C$. & Singkong & Perdu & Daun & 13 \\
\hline \multicolumn{5}{|l|}{ Famili Fabaceae } \\
\hline Vigna unguiculata $L$. & $\begin{array}{l}\text { Lembayung/Kacang } \\
\text { Panjang }\end{array}$ & Memanjat & Polong, Daun & 24 \\
\hline Psophocarpus tetragonolobus & Kecipir & Memanjat & Polong & 3 \\
\hline Phaseolus lunatus & Koro & Memanjat & Biji & 11 \\
\hline Leucanaria siceraria & Lamtoro & Pohon & Biji & 2 \\
\hline Sesbania grandiflora & Turi & Pohon & Bunga & 4 \\
\hline \multicolumn{5}{|l|}{ Famili Lamiaceae } \\
\hline Ocimum americanum & Kemangi & Semak & Batang, Daun & 16 \\
\hline \multicolumn{5}{|l|}{ Famili Moraceae } \\
\hline Artocarpus communis & Kluwih & Pohon & Buah & 6 \\
\hline Artocarpus heterophyllus & Nangka & Pohon & Buah & 1 \\
\hline \multicolumn{5}{|l|}{ Famili Poaceae } \\
\hline Bambusa sp. & Bambu & Pohon & Batang & 6 \\
\hline \multicolumn{5}{|l|}{ Famili Rubiacaea } \\
\hline Saprosma arbareum $B L$. & Sembukan & Memanjat & Daun & 2 \\
\hline \multicolumn{5}{|l|}{ Famili Solanaceae } \\
\hline Solanum melongena $\mathrm{L}$. & Terung Belatik & Semak & Buah & 6 \\
\hline Solanum torvum & Terung Pokak & Semak & Buah & 1 \\
\hline
\end{tabular}


Jurnal Biodjati, 2 (1) 2017

\section{JURNAL BIDDJATI}

http://journal.uinsgd.ac.id/index.php/biodjati

Penelitian mendokumentasikan 28 Kabupaten dan Kota Kediri disajikan pada spesies sayuran lokal milik 16 famili tanaman. Gambar 2.

Dokumentasi keragaman sayuran lokal di

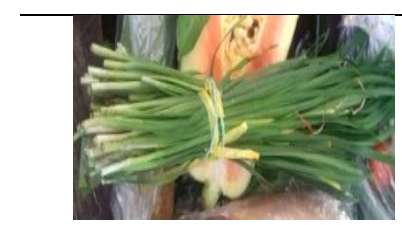

Kucai



Kenikir

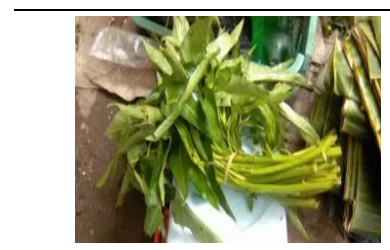

Kangkung

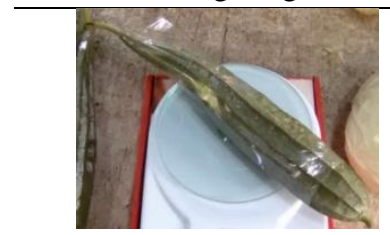

Oyong

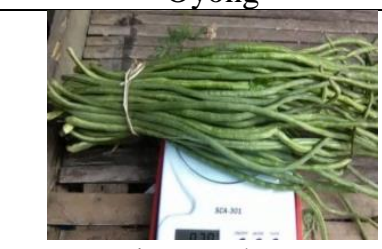

Lembayung/Kacang

Panjang

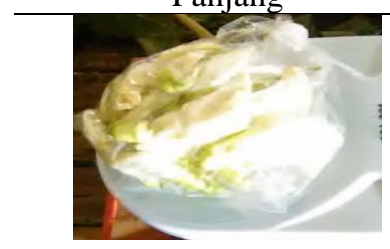

Turi

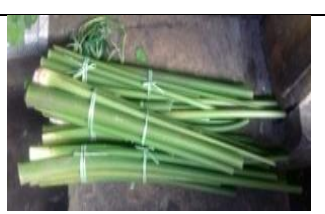

Lompong

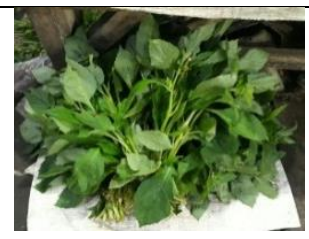

Sintrong

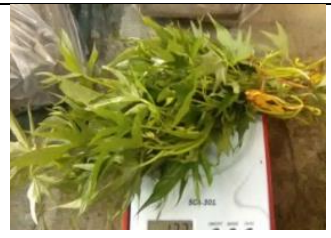

Ubi Jalar



Paria

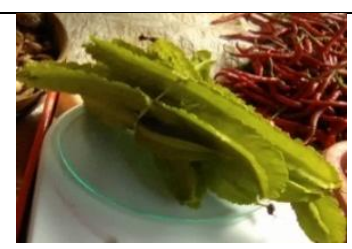

Kecipir

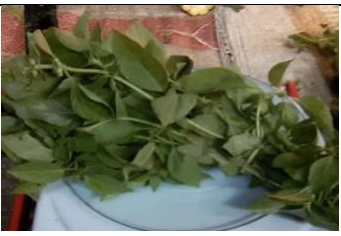

Kemangi

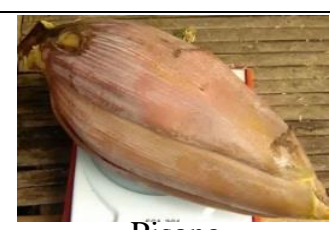

Pisang

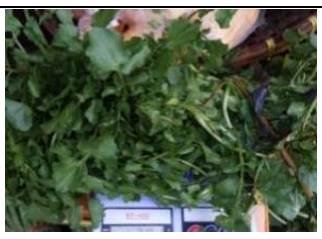

Selada Air

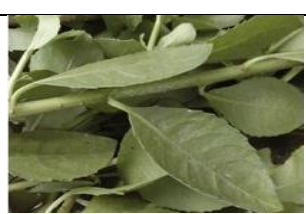

Beluntas

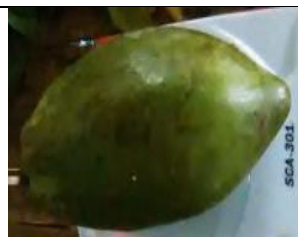

Pepaya

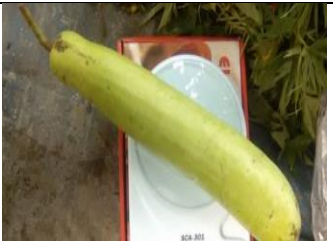

Blonceng

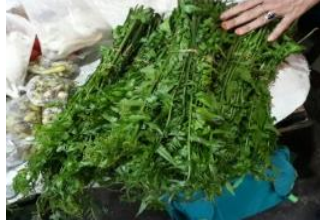

Pakis



Koro

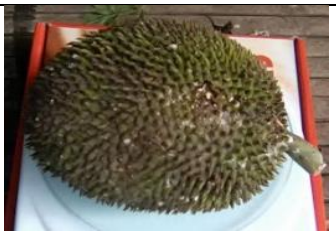

Kluwih

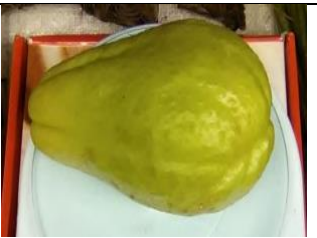

Labu Siam

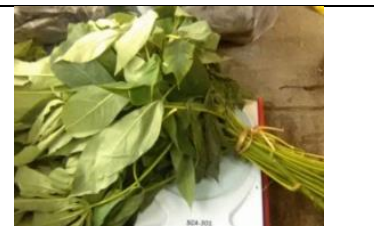

Singkong

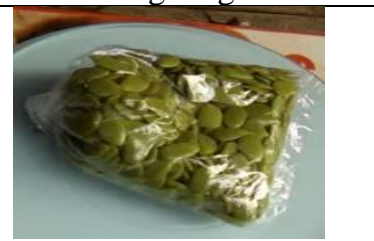

Lamtoro

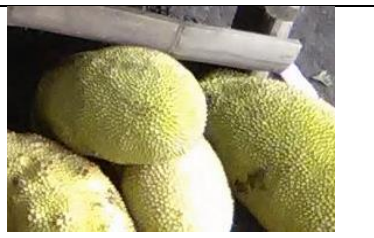

Nangka 


\section{JURNAL BIDDJATI}

http://journal.uinsgd.ac.id/index.php/biodjati

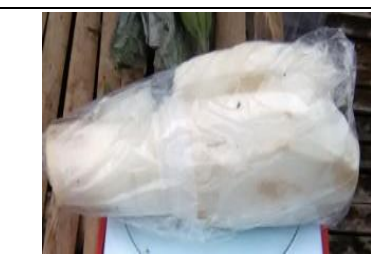

Rebung

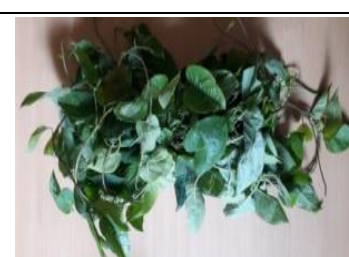

Sembukan

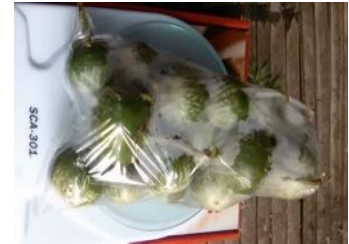

Terung belatik

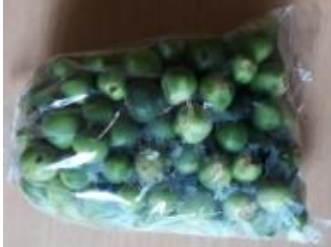

Terung Pokak

Gambar 2. Dokumentasi keanekaragaman sayuran lokal di pasar tradisional Kabupaten dan Kota Kediri.

\section{Sayuran Lokal Berdasarkan Daur Hidup Tanaman}

Berdasarkan daur hidup tanaman, 61\% dari tanaman yang ditemui pada penelitian termasuk tanaman semusim, sedangkan 39\% termasuk tanaman tahunan (Gambar 3).

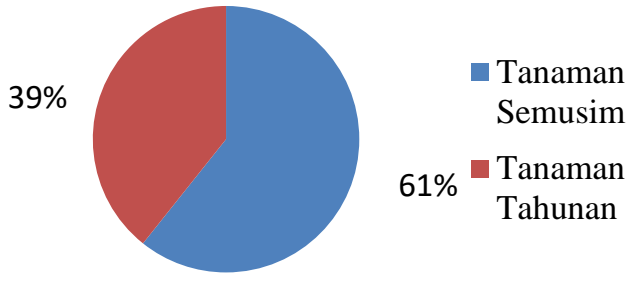

Gambar 3. Diagram persentase daur hidup sayuran lokal

\section{Asal Sayuran Lokal yang Diperjualbelikan}

Diantara sayuran lokal yang diperjualbelikan didapatkan $61 \%$ sayuran lokal yang dijual berasal dari pembudidayaan. Sebanyak $21 \%$ berasal dari pembudidayaan dan juga masih dipungut dari alam. Sisanya sebanyak 18\% sayuran langsung dipungut dari alam, tanpa proses pembudidayaan (Gambar 4).
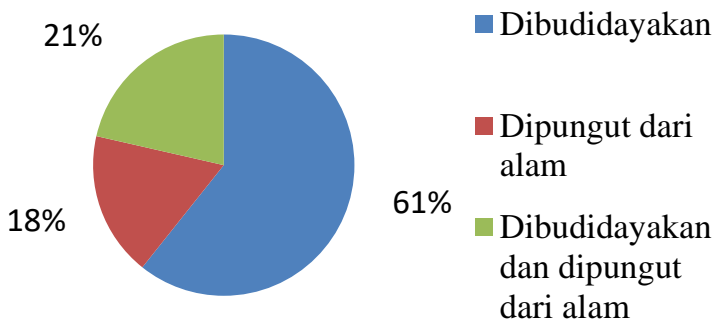

Gambar 4. Diagram persentase pembudidayaan sayuran lokal
Bagian Tanaman yang Dijual

Masyarakat daerah

tersebut

mengkonsumsi sayuran lokal dalam bentuk bunga, buah, batang, daun, biji dan polong. Bagian tanaman sayuran yang paling sering dijual berupa daun (36\%) dan diikuti oleh buah (25\%), batang $(22 \%)$, bunga $(6 \%)$, polong (6\%) dan biji (6\%). Diagram persentase bagian tanaman yang dijual disajikan pada Gambar 5.

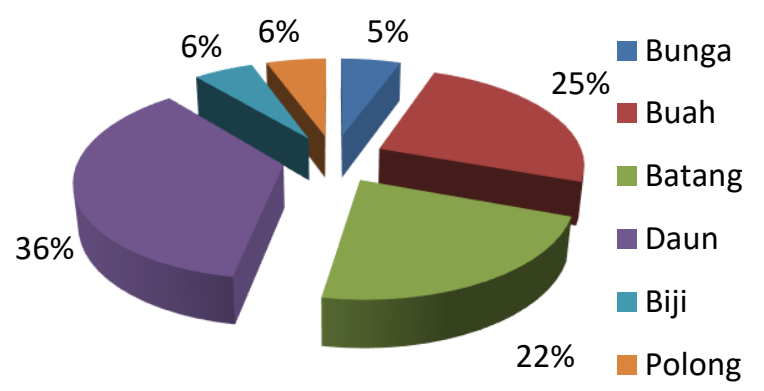

Gambar 5. Diagram persentase bagian tanaman yang dijual

\section{PEMBAHASAN}

Eksplorasi intensif dengan tujuan untuk pengumpulan informasi dan pendokumentasian sayuran lokal telah dilakukan selama 2 bulan dari Februari-Maret 2017 di 15 pasar tradisional Kabupaten dan Kota Kediri. Informasi dikumpulkan melalui wawancara semi-terstruktur menggunakan kuisioner. Responden penelitian terdiri dari 40 informan $(87,5 \%$ responden merupakan penduduk asli daerah tersebut, dan sisanya sebanyak $12,5 \%$ merupakan pendatang). Responden pada penelitian ini mayoritas 


\section{JURNAL BIDDATI}

http://journal.uinsgd.ac.id/index.php/biodjati

adalah penduduk asli daerah tersebut. Dengan harapan penduduk asli lebih banyak mempunyai pengetahuan tentang sayuran lokal daerah tersebut. Responden berjenis kelamin laki-laki sebanyak 6 orang dan perempuan sebanyak 34 orang. Mayoritas responden berjenis kelamin perempuan ( $85 \%$ dari total). Hal ini menjadi penting, karena perempuan lebih mempunyai ketertarikan pada sayuran lokal. Semua responden sudah berkeluarga, berusia antara antara 32 dan 81 tahun, yang didominasi oleh responden yang berusia 41-60 tahun $(57,5 \%)$. Dengan tingkat pendidikan terakhir dari responden yaitu $45 \%$ menempuh Sekolah Dasar (SD) dan 22, 5\% menempuh Sekolah Menengah Akhir (SMA), juga ditemukan masih terdapat $10 \%$ dari responden yang tidak menempuh pendidikan formal (Tabel 2).

Hubungan antara tanaman dan manusia sangat kuat dan tidak dapat dipisahkan, dapat dikatakan hubungan antara keduanya sebagai ketergantungan. Keanekaragaman tanaman menunjukkan kekayaan ekonomi dari suatu daerah. Pemanfaatan dan kegunaan dari tanaman tersebut berhubungan dengan arti penting tanaman di daerah tersebut (Arshad et al., 2014; Amjad dan Arsyad, 2014). Dalam penelitian ini, ditemukan bahwa masyarakat dari daerah penelitian tidak bergantung pada sayuran lokal untuk memenuhi kebutuhan dasar hidup. Beberapa sayuran lokal sulit untuk ditemui di sebagian besar pasar. Walaupun beberapa pasar memiliki keanekaragaman sayuran lokal yang tinggi, sebagai contohnya pasar tradisional Wates, yang terletak di daerah Kabupaten Kediri. Berdasarkan hasil wawancara dengan pedagang, didapatkan bahwa daerah tumbuh sayuran lokal berasal dari pedesaan. Di desa, sayuran tersebut lebih mudah ditemukan dan bernilai ekonomis rendah. Karena nilai ekonomis yang rendah, sayuran tersebut kurang mendapat perhatian. Adapun pedagang yang memperjualbelikan sayuran lokal di perkotaan mengharapkan adanya nilai tambah ekonomi pada sayuran tersebut, dibandingkan ketika dijual di desa. Pola konsumsi masyarakat perkotaan sekarang yang lebih menyukai sayuran kultivasi seperti kol, wortel dan lain-lain, membuat sayuran lokal terpinggirkan. Adapun keterbatasan lahan di daerah perkotaan menjadikan sayuran tersebut terbatas tempat tumbuhnya. Sehingga jarang ditemui sayuran lokal yang dibudidayakan di daerah perkotaan.

Hasil penelitian mendokumentasikan 28 spesies sayuran lokal milik 16 famili tanaman, sayuran tersebut dimanfaatkan sebagai pendamping makanan utama. Sayuran lokal dari hasil penelitian ini dapat mencerminkan besarnya keanekaragaman flora Kabupaten dan Kota Kediri. Keanekaragaman jenis sayuran lokal yang diperjualbelikan tergolong tinggi. Pasokan sayuran cenderung stabil dikarenakan sebagian besar sayuran lokal sudah dibudidayakan petani. Sebagian sayuran masih bergantung dengan kondisi curah hujan. Sehingga ada beberapa sayuran yang lebih mudah ditemui pada saat musim penghujan dibandingkan pada musim kemarau. Dari data frekuensi sitasi dapat terlihat bahwa sayuran lokal yang paling banyak diperjualbelikan adalah kenikir (24), kacang panjang (24), kangkung (23) dan kemangi (16). Sedangkan sayuran yang dijumpai paling sedikit diperjualbelikan adalah kucai (1), selada air (1), nangka (1) dan terung pokak (1). Jenis sayuran yang khas yang ditemui pada penelitian ini adalah sintrong dan sembukan. Kedua sayuran yang khas tersebut biasanya dikelompokkan pada tanaman gulma (gulma adalah tanaman tanaman kompetitor dan inang organisme pengganggu tanaman). Ternyata di daerah Kabupaten Kediri, tanaman tersebut termasuk sayuran yang biasa dikonsumsi dan dapat memberikan manfaat pada kesehatan. Langkah selanjutnya perlu dilakukan investigasi pada pemanfaatan sayuran dan kandungan komponen fitokimia tanaman 


\section{JURNAL BIDDATI}

http://journal.uinsgd.ac.id/index.php/biodjati

tersebut. $61 \%$ dari tanaman yang ditemui pada saat survey termasuk tanaman semusim, sedangkan $39 \%$ termasuk tanaman tahunan (Gambar 3).

Diantara sayuran tersebut didapatkan $61 \%$ sayuran lokal yang dijual berasal dari pembudidayaan. Sebanyak $21 \%$ berasal dari pembudidayaan dan juga masih dipungut dari alam, sisanya sebanyak 18\% sayuran langsung dipungut dari alam, tanpa proses pembudidayaan (Gambar 4). Sebagian besar tanaman dapat ditemukan dengan mudah di sekitar rumah, menunjukkan bahwa daerah penelitian kaya dalam biodiversitasnya. Pembudidayaan sayuran lokal bukan hanya bertujuan sebagai konservasi tanaman, tapi juga menjadikan sayuran tersebut lebih mudah untuk dikumpulkan. Sebagai tambahan, pada umumnya tanaman yang dibudidayakan dipekarangan rumah adalah tanaman yang sering digunakan oleh penduduk daerah tersebut (Zheng dan Xing, 2009).

Masyarakat setempat mengkonsumsi sayuran tersebut dalam bentuk bunga, buah, batang, daun, biji dan polong. Bagian tanaman sayuran lokal yang paling sering dimanfaatkan berupa daun $(36 \%)$ dan diikuti oleh buah (25\%), batang (22\%), bunga (6\%), polong (6\%) dan biji (6\%). Dalam beberapa kasus, lebih dari satu organ tanaman di satu macam spesies tanaman, seperti daun dan batang, dikonsumsi sebagai sayuran. Hasil penelitian kami ini sejalan dengan beberapa survey yang menunjukkan bahwa daun adalah bagian sayuran yang sering dikonsumsi (Susanti, 2015; Chotimah et al., 2013). Daun juga merupakan bagian yang paling dominan digunakan dibandingkan lainnya, karena bagian tanaman ini lebih mudah dikumpulkan dibandingkan bagian tanaman lain, buah dan bunga dan lain-lain (Giday et al., 2009). Dan dalam pandangan ilmiah, daun merupakan tempat fotosintesis dan tempat produksi dari metabolit sekunder (Ghorbani, 2005). Selain itu, alasan penting lainnya bahwa mengkonsumsi daun merupakan upaya untuk mengkonservasi tanaman, semisalnya kita mengunakan bagian akar akan menyebabkan tanaman tersebut mati dan menempatkan spesies tanaman tersebut dalam kondisi terancam kepunahan (Kadir et al., 2012).

Usaha budidaya sayuran lokal juga harus memperhatikan kajian ekosistem dimana tanaman tersebut tumbuh berkembang secara alami. Kajian mengenai karakteristik tumbuh tanaman pada habitat alami, $\mathrm{pH}$, komposisi media tanam, dan unsur hara harus dilakukan terlebih dahulu sebelum penanaman dilakukan. Kajian tersebut akan mempengaruhi teknologi budidaya yang digunakan dan modifikasi lingkungan tumbuh. Kemungkinan tanaman sayuran lokal menjadi gulma atau tanaman kompetitor dan inang organisme pengganggu tanaman juga harus mendapat perhatian khusus dalam rangka menciptakan lingkungan budidaya yang sehat. Usaha budidaya sayuran lokal juga harus memperhatikan aspek agribisnis agar dapat menambah nilai jual, jumlahnya sesuai permintaan pasar, dan pasokannya stabil. Harga jual di pasar dari semua sayuran lokal yang ditemukan berkisar di bawah Rp.8000,$/ \mathrm{kg}$. Harga sayuran lokal tertinggi adalah komoditas kemangi (Rp. 21.000/kg). Keberadaan sayuran lokal di pasar dengan harga yang relatif rendah dibandingkan sayuran kultivasi menunjukkan bahwa sayuran lokal dapat digolongkan sebagai sayuran minor.

Informasi tentang pemanfaatan sayuran lokal di Kabupaten dan Kota Kediri, Provinsi Jawa Timur, untuk pertama kalinya telah dikumpulkan dan didokumentasikan melalui penelitian ini. Penelitian kami menunjukkan bahwa sebagian besar sayuran lokal adalah pelengkap makanan utama untuk masyarakat di Kabupaten dan Kota Kediri. Hasil dari penelitian merepresentasikan informasi tentang 


\section{JURNAL BIODJATI}

http://journal.uinsgd.ac.id/index.php/biodjati

sayuran lokal, yang dapat berkontribusi memelihara kearifan lokal dan diharapkan dapat menarik minat generasi muda dalam pemanfaatan sayuran lokal. Hasil penelitian telah mendokumentasikan 28 spesies dari 16 famili tanaman. Penelitian juga diharapkan dapat menciptakan kepedulian antara masyarakat daerah Kabupaten dan Kota Kediri tentang arti penting dari sayuran lokal dan upaya konservasinya.

\section{UCAPAN TERIMA KASIH}

Ucapan terima kasih kami sampaikan kepada KEMENRISTEKDIKTI yang telah membiayai penelitian ini melalui program Penelitian Unggulan Perguruan Tinggi Universitas Brawijaya. Kami juga mengucapkan terima kasih atas bantuan yang diberikan oleh Amalia Azizah Ally selama pelaksanaan penelitian.

\section{DAFTAR PUSTAKA}

Abrori, M. (2016). Keanekaragaman tumbuhan bawah di Cagar Alam Manggis Gadungan Kecamatan Puncu Kabupaten Kediri. Skripsi, Universitas Islam Negeri, Malang.

Amjad, M. S., \& Arshad, M. (2014). Ethnobotanical inventory and medicinal uses of some important woody plant species of Kotli, Azad Kashmir, Pakistan. Asian Pac. J. Trop. Biomed 4, 12, 952958.

Arshad M., Ahmed M., Ahmed E. Saboor A., Abbas A., \& Sadiq, S. (2014). An ethnobotanical study in Kala Chitta Hills of Pothwar Region. Pakistan: Multinomial logit specification. J. Ethnobiol Erhnomed, 10, 13.

Becker, K., Afuang W., \& Siddhuraju, P. (2003). Comparative nutritional evaluation of raw, methanol extracted residues and methanol extracs of moringa (Moringa oleifera Lam.) leaves on growth performance and feed utilization in Nile Tilapia (Oreochromis niloticus L.). Aquaculture Research 34, 13, 1147-1159.

Caton, B. P., Mortimer, M., Hill, J.E., \& Johnson, D. E. (2010). A practical field guide to weeds of rice in Asia. Philippines: International Rice Research Institute

Chotimah, H. E. N. C., Kresnatita, S. \& Miranda, Y. (2011). Studi etnobotani sayuran indigenous (lokal) Kalimantan Tengah. Jurnal Seminar Nasional Fakultas Pertanian Universitas Trunojoyo. Solo.

FAOSTAT. (2007). Food agriculture organization corporate statiscal database FAOSTAT on-line, United Nation Food and Agriculture Organization, Rome. Retrieved from. http://faostat.fao.org/defa ult.aspx.

Ghorbani, A. (2005). Studies on pharmaceutical ethobotany in region of Turkmen Sahra, North of Iran (Part 1) General Results. J. Ethnopharmacol, 102, 58-68.

Giday, M., Astaw Z., \& Woldu Z. (2009). Medicinal plants of the Meinit ethnic group of Ethiophia: an ethnobotanical study. J. Ethnopharmacol, 124, 513-521.

Grubben, G. J. H., Siemonsma, J.S., \& Kasem, P. (1994). Introduction to plant resources of South-East Asia 8: vegetables. Bogor: PROSEA Foundation.

Kadir, M. F., Bin Sayeed, M. S., \& Mia, M. M. K. (2012). Ethnopharmacological survey of medicinal plants used by indigenous and tribal people in Rangamati, Bangladesh. J. Ethnopharmacol, 144, 627637.

Madalla, N., Agbo, N.W., \& Jauncey, K. (2013). Evaluation of aqueous extracted moringa leaf meal as a protein source for 


\section{JURNAL BIODJATI}

http://journal.uinsgd.ac.id/index.php/biodjati

Nile Tilapia Juveniles. Tanzania Journal of Agricultura Science, 12, 1, 53-64.

Marsh, R. (1998). Building on traditional gardening to improve household food security. Food Nutr: Agric., 22, 4-14.

Naidu, V. S. G. R. (2012). Hand book on weed identification. directorate of weed science research. India: Jabalpur.

Pugalenthi, M., Vadivel, V., \& Siddhuraju, P. (2005). Alternative food/feed perspectives of an underutilized legume Mucuna pruriens Var. Utilis - a review. Plants Foods for Human Nutrition, 60, 201-218.

Rosyetti. (2009). Studi keterkaitan pertumbuhan penduduk dengan pembangunan ekonomi di Kabupaten Kuantan Singing. Jurnal Ekonomi, 17, 2, 51-63.

Sari, D. A.W., \& Santoso, E.B. (2016). Faktorfaktor yang mempengaruhi pengembangan komoditas unggulan Hortikultura di Kawasan Agropolitan Ngawasondat Kabupaten Kediri. Jurnal Teknik, 5, 1, 6469.

Suryadi \& Kusmana. (2004). Mengenal sayuran indijenes, monografi no.25. Bandung: Balai Penelitian Tanaman Sayur.

Susanti, H. (2015). Ethnobotanical study for swamp Lokal vegetables at Martapura Market of South Kalimantan. Ziraa'ah, 40, 2, 140-144.

WCMC. (1992). Global biodiversity: status of the earth' living resources - world conservation monitoring centre. New York : Chapman and Hall.
Zheng, X., \& Xing, F. (2009). Ethnobotanical study on medicinal plants around Mt. Yinggeling, Hainan Island, China. J. Ethnopharmacol, 124, 197-210. 